\title{
The Pattern of Islamic Moderate Movement in Java under Political Fluctuations in Early 20th Century
}

\author{
Nostalgiawan Wahyudhi ${ }^{1}$ \\ ${ }^{1}$ Centre for Political Studies, Indonesian Institute of Science (LIPI) \\ Jakarta, Indonesia.
}

Email:wan_jauzy@yahoo.com

\begin{abstract}
:
The previous studies of Islamization in Java follow a clear distinction of Priyayi-Abangan-Santri thesis, which was gradually developed and incompatible to capture the changing of political preferences of Javanese Muslims. This paper examines what kind of patterns formed on the dynamics of the Islamization process in Java under the influence of socio-political changes. The output of this paper is to show the pattern of Islamization process in Java under the political dynamic changes of Indonesian politics in the early twentieth century. The pattern of Islamization in Java was influenced by ethical policy, the transmission of Middle East Islam, and caused by the politization of Islam by the Colonial government. The ethical policy encouraged the creation of a public space for political contestations that determined the new identity of Indonesian elite. The transmission of Middle Eastern Islam triggered the polarization of Javanese Muslims into two patterns: the modernist Muslim strengthened the pattern of Priyayi-Santri in urban communities with Islamization through modern institutions. In this, the traditionalist Muslim also developed an intellectual genealogy through Pesantren networks scattered in the rural areas created the pattern of Santri-Abangan. Meanwhile the politization of Islam by Colonial government created a benefit to the unification of Islamic institutions.
\end{abstract}

Keywords: Islamization, Politization, Genealogy, Traditionalist Muslim, Modern Muslim.

\section{A. INTRODUCTION}

Syncretism in the Javanese Islam is a very interesting study as a research conducted by Clifford Geertz (Geertz, 1976) provides a very influential anthropological map in Islamic studies on a stratified Javanese community in relation to religion and power that are depicted in a strict preference over political choices: priyayi, santri and abangan. Priyayi represents an aristocraticbureaucrat position that occupies the highest caste in the socio-political structure of Java, which is affiliated to the Indonesian Nationalist Party (PNI), while santri is a representation of a middle caste from religious backgrounds that has a strong affiliation to Masjumi. Abangan is the lowest caste that represents the farmers and affiliated to the Indonesian Communist Party (PKI) and PNI. These assumptions are based on the approach of Geertz (Geertz 1973, p. 87-125) stating that religion determines the pattern of human behavior.

In his book about Javanese Islam, Ricklefs $(2013$, p. 49-54, 111-113) represents himself as a new Geertzian where the backbone of his analytical writings uses the framework of Geertz's thesis within a historical-culturalist approach. He indicates the dynamic changes of relationships 
between priyayi, santri and abangan since 1930 until post-reformation Indonesia as a leading indicator of tidal process of Islamization in Java. Ricklefs regards that syncretism is an important element in the spirituality of Java society which he describes as the mystical synthesis that composed on the basis of: consciousness of strong Islamic identity which defines the Javanese means to be Muslim; comprehensive implementations of the five pillars of Islam; regardless of the contradictions on the two pillars above, the Java community trust magical powers and supernatural (spiritual local forces) as Ratu Adil (messiah), Nyi Roro Kidul, Sunan Lawu and others (Ricklefs, 2007, p. 11).

The syncretism in the Javanese Islamic community has strongly been a tradition since the 16th century. It has been reflected in their socio-spiritual life as how Kiswah pieces ${ }^{1}$ were considered as amulets, mythical stories of the pilgrims who perform hajj from Makkah, or the myths of spiritual strength of the Javanese ulama as evidences of how syncretism is crucial in the spread of Islam in Java (Bruinessen, 1995, p. 42-48). At a certain point, the practice of Islam is conducted by the Javanese have been described as modifications or built under the influence of Hindu (Crawfurd, 1820 , p. 260-271) or in the language of Raffles as the accumulation of two different religious delusions (Raffles 1830, p. 3-4) rather than as a religion that has theological roots and praxis that is completely different. In this case, both Crawfurd (Crawfurd, 1820) and Raffles (Raffles 1830, p. 5) agree to say that the Javanese community in the Netherlands East Indies under the British occupation was not a perfect follower of Islam or imperfect Mohammedans.

Seen from the above analysis that most scholars give greater emphasis to syncretism and social stratification as a dominant factor in the study of Javanese Islam, but but it would be a very delighting to explore Javanese Islam in the context of the changing socio-political environments that has existed since the beginning of the 20th century where islamization has developed in the Java community in a dynamic process. This approach is attributed to investigate what kind of patterns formed on the dynamics of the process of Islamization in Java under the influence of socio-political changes.

The concept of Islamization in this study is not literally defined as a form of religious conversion but rather as a gradual process of public relationships that creates intense communication, response, adaptation, and mutual exchanges of virtues and values faced by the Muslim community in maintaining their Islamic identities. The meaning of islamization covers various aspects i.e. as a spiritual dimension that used by Anthony $\mathrm{H}$. Johns to reflect the dynamic movements of Sufism (Johns, 1993), and as reclaiming the authorities of science and knowledge (Islamization of knowledge) which are carried by Ismail Raji al-Faruqi (Ismail Raji Al-Faruqi, 1982, 1988) and Naquib al-Attas (Al-Attas 1991). But the meaning of Islamization that emphasized in this paper is the revitalization of Islam in response to changes in socio-political life that happens in Islamic societies, in this case the Java community. So that the relation between Islamisation and politics in the early 20th century will be seen from two approaches: first, religion is considered as a tool of political legitimacy in the Javanese community. Second, Islamization is a gradual process that is associated with the socio-political environment. Of the two approaches, we see that Islamization is a dynamic process that is directly related to the changing of socio-political environments, because Islam and the Islamization are often used as an instrument of political legitimacy.

\footnotetext{
${ }^{1} \mathrm{~A}$ piece of black cloth as a part of the cover of the Kaaba building that usually has been cutted by Javanese pilgrims during their Hajj performances in Makkah.
} 


\section{B. METHODS}

This paper used the dynamics of the process of Islamization concept related to the influence of socio-political changes. The pattern of islamization in Java follows the dynamic changes of Indonesian politics in the early twentieth century.

\section{RESULT AND DISCUSSIONS}

\section{Legitimacy and Gradual Process of Islamization in Java}

It is difficult to doubt that the origins of the belief system of the Java community besides animismdynamism. It is similar to Islam; Hinduism entered Indonesia through the transmission process. This transmission process affects the formation of patterns of legitimacy that occurred early in the Javanese community. During the reign of Majapahit, the Javanese community has been influenced by the political process of Indianization, interconnection of Javanese people to the international environment especially India to strengthen Hinduism as a part of political and religious legitimacy of Majapahit kingdom since the 8th century. Religiosity of the Javanese community deephened by the process of equating the name of territories of the Hindu's power in India as described in the book of Bharatayudha into the philosophical-political region of Javanese island. It is an imaginary representation of Java as the blessed land to potentially encourage the belief that the HinduMajapahit as the centre of power. The diplomatic relations to India has also done through the process of religious transmission by sending Javanese students to learn the teachings of Hinduism. In politics, the religious leaders had an important role as the advisor of the king and managed religious rituals to become a tradition from the palace to the grassroots (Raharjo, 2002, p. 40-47, 167-179).

This pattern also occurred during the Islamic kingdoms of Java where the range of the 1630 s, Banten and Mataram kingdoms competed in sending students to Makkah, as well as to deepen the teaching of Islam and to expand the distribution of religious scholars in their territories. The Islamic kingdom was also seeking recognition as a part of the great empire of Islam (Dār al-Isläm) in the Middle East and celebrated the title of 'Sultan' from Syarif Haramayn (Makkah and Medina) (Djajadiningrat, 1913, p. 49-52, 174-178). Performing Hajj to Makkah within Javanese people was considered as part of worship ('ibāda) but also to give a supernatural power that strengthened the legitimacy and social status in the Javanese community (Crawfurd, 1820, p. 260-271).

Ricklefs's understanding of the mystical synthesis has to be explained as an attempt to seek political legitimacy as a proof that the religion of Islam has sustained in Java through a gradual process. The Javanese people in the analysis of Ricklefs was an accommodationist Muslim who still tolerate paganism (syirk) that it is strictly prohibited in Islam and contrary to the nature of the teachings that embrace monotheism. Because the Java community culturally still believe in the existence of magical powers and supernatural dimensions. This underlines what the Kuntjaraningrat understanding that the origin of Javanese culture is an open society (Ember and Ember, 1994, p. 30-31), where Hindu-Buddhist as new religions in the Javanese's animism-dynamism society has arrived through the process of transmission in the $8^{\text {th }}$ century (Raharjo, 2002, p. 40-47). Likewise, Islam that came and assimilated afterwards is also a new religion that has acculturated gradually with syncretic culture patterned Javanese Hindu-Buddhist. This openness appears on greeting of the king Brawidjaja in the Babad Diponegoro to the messengers of Campa, Sayid Rahmat and Sayid Rahman, who received positively the presence of Islam in Java (Feillard, 2011, p. 45). This statement is also mentioned in the research conducted by Dhofier on pesantren in Java and Anthony 
Johns on Sufism in Southeast Asia that the spreading of Islam has accomodatively interacted with social, economic, political and cultural aspects of Javanese society (Dhofier, 2011, p. 11-15; John, 1993.).

Social stratifications in the thesis of Geertz (priyayi, abangan, and santri) are a form interaction between Islam and Javanese culture that has been affected by the culture and religions of Hinduism and Buddhism. The spreading of Islam through Sufism approach provides sufficient tolerance against the local elements (the Hindu-Buddhist rituals and traditions that have rooted before) so that, at a certain level, Islamic practices in the Java community has a significant gap with the norms of originality teachings of Islam itself. However, Sufism provides benefits to the spread of accommodative Islam in the Javanese community (Madjid 2013, p. 84-85).

\section{Ethical Policy and the Creation of Public Space for Islamization}

At the end of the 19th century and also known as the age in motion (Shiraishi, 1990) or the ideological decades (Abdullah, 1987, p. 15), Islamization is growing rapidly along with the social and political changes in the Javanese society. During this time, islamization has faced another step of challenges that is ideologically more critical and politically instable. The ethical policy conducted by the Dutch government did not only change the socio-economic structure but also socio-political conditions of Indonesian society. It provided a space for the Indonesian people to get an access to education, especially for the middle class.

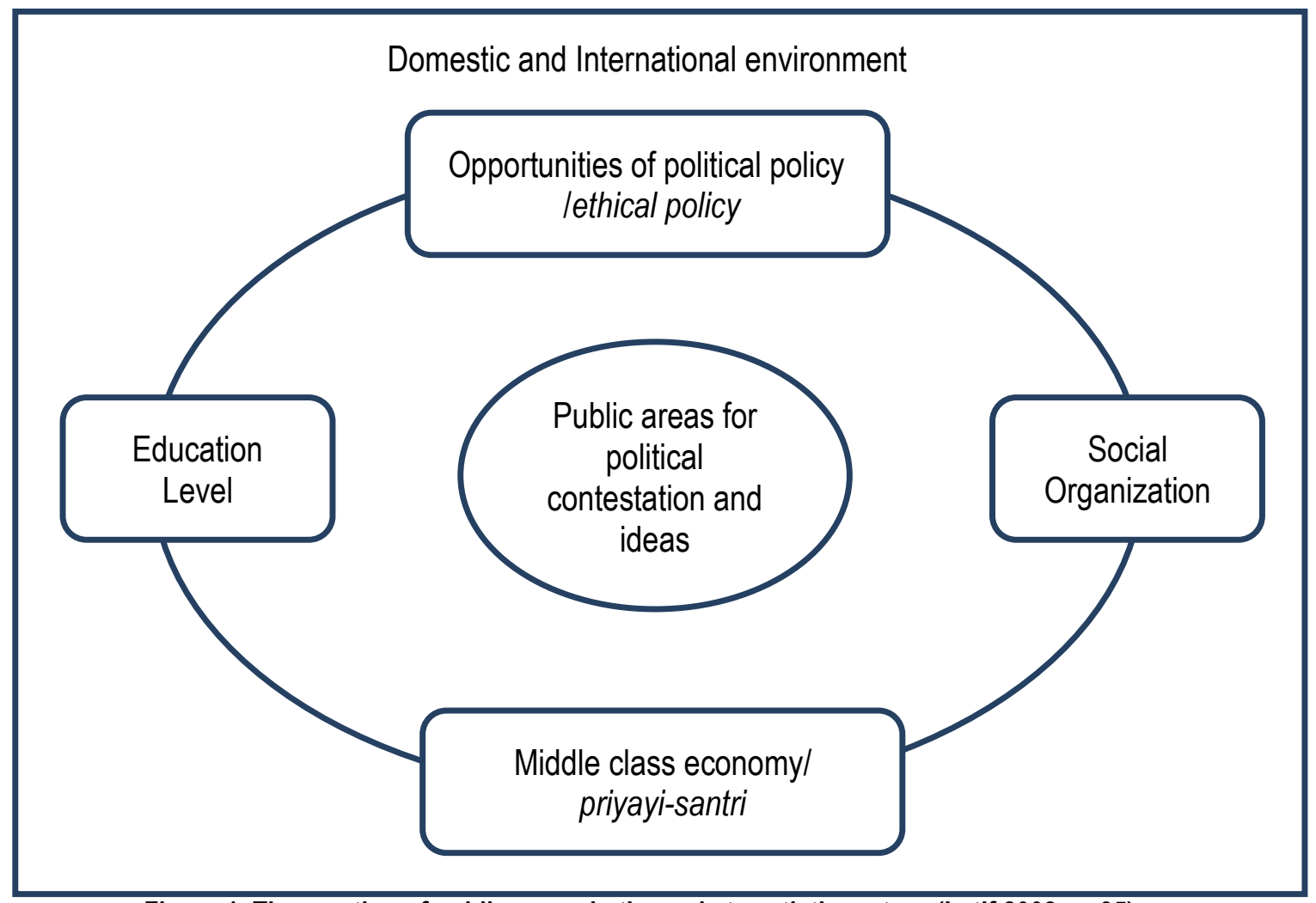

Figure 1. The creation of public space in the early twentieth century (Latif 2008, p. 35).

In his book, van Niel (Niel, 1960, p. 314)considers that ethical policy was crucial for the growth of a new representation of the Indonesian elites to fight against colonialism in a modern, structured and organized action, which indirectly represented destratification of Geertz's thesis on priyayisantri-abangan. However, comparing to the study of Geertz (Geertz 1961, p. 604-606), van Niel is systematically failed to disclose on the side where the idea of this ethical policy could have an 
impact on the socio-political dynamics in Indonesia, since the fact that the rise of social and political movements Indonesia was the failure of the relationship between colonizers and colonized. In this case Geertz as if to underline that the growth of the resistance movement against colonialism was not part of the goal of the ethical policy of the Netherlands. According to Latif (Latif 2008, p. 35), regardless of his disapproval towards van Niel and Geertz, in his analysis of the growth of the Muslim intelligentsia in Indonesia, ethical policy is not the only factor to strengthen the rise of socio-political organization in Indonesia. He reveals that other factors such as increased levels of education, economic, and political policy have provided the availability of the public domain for the emergence of the contestation of ideas and movements against colonialism. Since the ulama has occupied the domain of political action, Islamization melted within the spirit of nationalist and anti-colonialist movements. This movement is not frontal, although in the frame education, thought and socio-religious movements but politically to be strong during the rise of Indonesian nationalist movements.

In the tought of Hebermas, the creation of public areas can be interpreted as the collectivity of social awareness in Javanese community to conduct collective responses to the problem of colonialism has exceeded the limits of the private area and into the problems of broader society (Hebermas, 1991, p. 301; Susen 2011). The process of Islamization also benefited from the creation of this public area. Increased levels of education and economy of the Indonesian people followed by a growing awareness of the massive ideological movements both from nationalists and Islamists strengthened the struggle for the state independence. The growth of ideological Islamic organizations in the urban society of Java such as modernist Islamic movement Jamaat Al-Khair (1901), Sarekat Islam (SI, 1912), and Muhammadiyah (1912) were also benefitted from the creation of this public area (Latif 2008, p. 119-125, 130). On the other hand, the availability of public areas also encouraged the growth of a rural-based movement of traditional Islamic organization i.e. Nahdlatul Ulama (NU, 1926) in East Java as a counterweight on the development of modernist Islamic movements that highly dynamic and organized on issues of nationalism, modernism and contemporary issues in the Muslim world such as the formation of Hejaz committee for international Islamic congress (Yusuf, Syam, and Mas'udi, 1983, p. 18-19).

Important aspects that do not mentioned by Geertz is the dynamic developments of priyayi, santri and abangan during the colonial time because, in further development, priyayi has no longer to become the major factor of elite determination that assigned the social stratification in the Javanese society. Public areas created a new definition of Javanese elite that is no longer monopolized by the aristocracy genetic line, but was determined by the aspect of education, economics, and leadership. The political movement and Islamization in Java was led by the elite and middle-class Indonesia who transcended the dichotomy of priyayi, santri and abangan. The birth of Muslim intelligence figures like Cipto Mangunkusumo, Tirto Adhi Suryo, Tjokroaminoto, Ahmad Dahlan and the other was the Portrait of development of priyayi who had a family background of santri (priyayi-santri) from Indonesia's middle-class society that had ability to access to education. The figure of priyayi-santri would greatly affect the growth of Islamization in Java (Latif 2008, p. 5). In addition, Geertz and Ricklefs also inaccurate in observing the process of regeneration of pesantren and santri of the traditional Islam that used the lines of intellectual genealogy to revitalize the islamization process. This method became a starting point of the existence of traditional Islam in public areas by taking the rural niche as the basis of movements, which in turn will melt them to the grass root of Javanese society to form the pattern of santri-abangan (Dhofier, 2011, p. 102-113, 129-142). 


\section{Javanese Islam and the Transmission of Islam From the Middle East}

The transmission of Islamic movement from international sphere especially from the Middle East has taken place since the beginning of the 20th century. In the context of islamization in Java, this transmission functioned as a revitalization of Islam that has moved through the individual (hajj) and journals, especially since the discovery of the steam vessel and printing technology. Individual transmission has done through the Javanese pilgrims who settled in Makkah (Jawi colonies) and also young santris who learned to the scholars in Makkah, especially scholars of Indonesian descent like Arshad al-Banjari (d. 1812), al-Nawawi Bantani (d. 1898), Mahfudz Tremas (d. 1920) and Ahmad Khatib (d. 1916). The latter, Ahmad Khatib, was the imam in Makkah from Minangkabau descent who had a major influence in instilling the spirit of anti-colonialism to his students of whom Agus Salim, Ahmad Dahlan and Hasyim Ashari who later became the founder of influential Islamic organization in indonesia such as SI, Muhammadiyah and NU (Nazwar, 1983; Geertz, 2001).

In the articles referring to Burton, Vredenbergt and data from the Ministry of Religion in 1965, Noer (2000, p. 3-4) concludes that since the mid-19th century population of Indonesian pilgrims was at the highest level compared to other countries. The fluctuation of Indonesian pilgrims was always in numbers of 2000 to 15,000 worshipers. Only in 1926 the population jumped to 52.412 worshipers. This amount is very striking because for the first time that amount passed at the hajj in 1975 after the independence of the state, where pilgrims Indonesia reached 65,000 people. However, this data according to van Bruinessen (Bruinessen, 1995, p. 50-51) cannot be trusted, because from different sources, in the range of 1925-1926, he found that there were only 3,500 Indonesian pilgrims in Makkah. The differences of the data are very understandable due to the limitations of organized administration at that time. At least this data emphasizes that the interconnection of Islam in Java and the Middle East through the Hajj gives a very significant impact to the process of Islamization in Java.

Hurgronje noted that there are two polarized attitudes of Jawi colony during their activities in Makkah. The elderly tended to maximize their worships in sacred and efficacious places, while younger groups attracted to engage in intellectual activities such as studying Islam from the scholars of Makkah and followed the development of ideas of Islamic modernism in Cairo. This regeneration process is very important; at least the specified pattern is pushing the middle religious people (priyayi-santri) to send their descendants to the center of Islamic scholarship in Makkah (Abaza, 1999, p. xvii-xviii). Other Islamization pattern was the arrival of migrant scholars from the Middle East to Indonesia i.e. a Sudanese scholars, Ahmad Surkati, who was active in modernist Islamic organization Jamaat Khair and Al-Irshad which have a crucial influence on the Hadramis in Java (Abushouk, 2001; Lukas 2002).

Aside from the pilgrimage path, the modernist journals that were the main reference of the Middle East scholars such as al-'Urwah al-Wuthqā and al-Manār have transmitted to Java through the Hadrami networks in Batavia and Singapore (Abushouk, 2007; Ricklefs, 2008). The influential figures of hadrami like Sayyid Hassan b. Shihab (d. 1912), Sayyid Abu Bakr b. Shihab (d. 1922) and Sayyid Muhammad b. Aqil b. Yahya (d. 1931) had a greatly contribution in spreading the ideas of Islamic modernism and became representatives of the spreading of modernist journals in Java (Abushouk, 2007). The strong interconnection between Java and Singapore can be based on the composition of Singapore population that time made up of Malay-Indonesian, Arabic-Hadrami, Indian, Javanese descent workers, santri and pilgrims who transitted and settled there (Ricklefs, 2008), 2001, p. 212-214). Singapore was a melting pot for the people to transit, gather, and disseminate the ideas of modernist Islam from various ethnic groups in Southeast Asia especially Java and Sumatra (Taylor, 2003). The presence of al-Manār has triggered the publication of similar 
journals among modernist Islamic movement in Java, such as the journal al-Islā $m$ belonged to SI (Korver, 1985, p. 100), al-lqbāl (Java), al-Mir'at al-Muhammadiyah (Yogyakarta), and al-Irshād (Pekalongan) (Azra, 1999).

For the modernist Islam, the pattern of Islamization is formed through the establishment of socioreligious organizations that are structured and organized to establish a modern Islamic school which combines the secular and Islam teachings. The idea of modernist Islam is actually the purification of Islam, by renewing and reforming the religious practices that is contrary to the teachings of Islam, especially reforming the confounding practices related to worshiping ('ibāda) for example local beliefs and traditions i.e. syncretism that would be contradicted the principle of monotheism of Islam, but it would be very open to renewal tradition that related to non-worshiping practices such as modernity. The modernist Islamic movement in Indonesia has very much affected by the development of Islamic modernist ideas in Cairo as the thought of al- Afghān (d. 1890), Abduh (d. 1905) and Rashid Ridha (d. 1935) or in South Asia as al-Mawdudi(d. 1979) (Abushouk, 2007). However, the most important thing to observe is the implication of the thoughts and ideas of Islamic modernism in the Javanese society during their activitivism in organizations and distribution of ideas through printing media that has influenced the movement of Islamic organizations such as Jamaat Khair, al-Irshad, Sarikat Islam, Muhammadiyah, Persis, and Masjumi. Through these institutions and memberships, syncretism was significantly eroded within the Javanese society, especially in urban areas.

For the traditionalist ulama of Java, Mahfud Tremas, the influenced ulama in Makkah, provided the deep impact on the development of Islamization among pesantren (traditional boarding school) in Central Java, East Java and Madura. His talented santri, Hasyim Asy'ari, brought the influences of Mahfud Tremas to his pesantren named Tebuireng, at Jombang district in East Java province, after studying in Makkah (Bruinessen, 1995, p. 37-40). Through the research conducted by Snouk Hurgronje, Dhofier (Dhofier, 2011, p. 69, 137-139) argues that intellectual genealogy has been constructed through self-organizing efforts of the scholars and santris of Jawi in Makkah and Medina. The establishment of Madrasah Dār al-Ulūm al-Dīniyya in Saudi Arabia which accommodated about 5,000 students (50 percent of the total students are foreigners) enforced the jawi students in Makkah to imitate the similar school development in their land. It becomes the root of the genealogy of pesantren and the intellectual traditions of the traditional Islam in Java.

The young santri who returned from Makkah established traditional educational institutions (pesantren), which made the Islamization process spreading rapidly in rural areas, especially in Central Java, East Java and Madura. J.A. van der Chijs notes that at least in 1873 there were as many as $20,000-25,000$ boarding schools developed in Java, which have accommodated up to 300,000 students. The alumni of these santri have spread in almost all rural areas in Java and became religious leaders (kyai or ustad) in the villages. Because it is no wonder several major pesantrens that still exists today were established since the 19th century such as pesantren of Tremas, Jampes, Bendo, Pelangitan, Tegalsari, Tebuireng, Bangkalan, Tambakberas and etc. (Latif 2008, p. 68, 141).

These pesantrens used the traditional teaching methods and did not teach secular subjects, but rather on reviewing the classic books (kitab kuning) that homage to the Shafi'i school, the school of majority Javanese people. They used Sufism approaches (tareqat), which was very vital for the sustainability of Islamization in Java. From his study about the genealogy of the intellectual tradition of pesantren in Indonesia, Martin van Bruinessen (Bruinessen, 1995) emphasizes the importance of kitab kuning in shaping the Sufism practices in various traditional Javanese pesantren. It has been a vital energy for the regeneration of traditional Islam in Indonesia and is also important to 
explain the genealogy of scholars and their profound influences to the santri and abangan in the island of Java. But in its development, Dhofier (Dhofier, 2011, p. 75) notes that the pesantren has adapted the reformism ideas in the field of education to maintain their vitality to compete with modern schools. The contemporary pesantren in Java can be grouped in two major types: 1) pesantren that are still keeping the classical tradition in its curriculum such as the pesantren of Lirboyo, Ploso, Maslakul Huda and Tremas. 2) Pesantrens that are combining Islamic and secular curriculums by establishing formal schools in cooperation with the Ministry of Religion such as the respected pesantrens of Tebuireng and Rejoso.

At the second generation, the pattern of this intellectual genealogy is realized by the alumni santris of Tebuireng who have spread and established of new pesantrens which have similar curriculums and method of teaching that they have learned from Hasyim Asy'ari. The pattern shown by this intellectual genealogy is a structural pattern in which the position of the pesantren of Tebuireng celebrates as the most prestigious and elite institution as the initial trigger of intellectual genealogy of the traditional schools. Dhofier argues that the studies that have been conducted by Geertz on his books of Islam Observed (1968), Religion of Java (1976) and also by Deliar Noer (Noer, 1973) about Modernist Movements caused misunderstanding in defining traditionalist Islam as the 'conservative' group (kolot). This makes most scholars who study Islam in Java deny the role of Kyai and pesantren as the vanguard of the process of Islamization in the grassroots who are also gradually eroding syncretism among abangans (Dhofier, 2011, p. 75).

Ricklefs (2013, p. 75-92, 92-111, 103, 316-318) seems to give a special portion and details on the existence of Javanese syncretism around the 1930s in Kraton (palace) and Javanese society, as well as the polarization of traditionalist Islam in several small sufism groups (tarekat). It is actually positive contributions, but at some point, will reduce the important role of modernist Islam in Java such as SI, al-Irshad and Muhammadiyah as well as the role of traditional Islam. On the other hand, the study of Ricklefs or Geertz can not be generalized as a portrait of Javanese Islam, where anthropological studies of Pranowo in the area Tegalroso show that a personal religiosity and faith in Javanese society can not be measured structurally (Pranowo, 2011, p. 363-368). The barrier between santri and abangan is not always that clear. According the criteria given by Geertz, the majority of Tegalroso society is categorized as abangan but in fact their affiliation are not identically to PNI or PKI because as an individual, the people of Tegalroso are more comfortable regarded as a Muslim group (santri). Their decisions to choose PKI as a political preference were not decreased their identity and spiritual belief as Muslim (Pranowo, 2011, p. 135-141).

\section{Islamization and Politization of Islam in Colonial Time}

Political Islam has an impact on the socio-political changes in the lives of Javanese Muslim. According to Aqib Suminto, the policy of kristeniing politic (the politic of Christianization) has already been since 1901 when the right-wing Christian parties occupied elections in the Netherlands. The message in the official speeches of Queen Wilhelmina in September of the same year expressed the support for the Dutch government to the Christian mission in Indonesia. Idenburg, the governor general in Java, created policies that gave major supports to Christian missionaries and applied a discriminatory funding policy to Javanese Muslim by providing bigger funding to Christian mission rather than Islam as the religion of the majority (Nasution, 2001, p. 15 ,Kahfi, 2001, p. 19).

W.H. Alting von Geusau (1917) notes some discriminatory policies of the Netherlands and summarized in Referring Reglement, Referring's Almanac and some strict licensing policies of Hajj, ulama, funding for mosques, wedding, and inequality of the funding towards Muslims and the 
mission of Christianization. This policy has created protests both from the santris, 'ulamās and regents in Java and Madura towards Idenburg. Especially since 1905, every ustad (religious teacher) and 'ulamā' had to obtain a license and permission from the Dutch government for every activity (Suminto, 1985, p. 20-31). The spread of Christianization during the reign of Idenburg peaked, because he actually disagreed with article 119 of Law 1855 which prohibited the Dutch government to interfere in religious activities. Suminto noted the Idenburg controversial statement that "the Dutch will always colonized the East Indies until the Christian become religion of the peoples" .

In Suminto analysis, the most obvious politicization occurred at the Kantoor voor Inlandsche Zaken (the Office of Indigenous Affairs). This institution was established to mediate the Dutch government and the native people. Although it often supported soft colonial approach to the natives, but this institution also had a role to monitor the movement of natives and reported it to the colonial government, especially about Islam. This is the reason of why the people refer this institution as the office of religious institution, beside this institution headed by Dutch scholars who study Islam. The policy of this institution often exaggerated, especially under the leadership Snouck where this institution proposed to oversight and to restrict on the financial management of mosques especially at progressive areas in Java such as Ponorogo, Kutoarjo, Pekalongan, and Banyumas. The Dutch colonialism also rebuked the regent of Pasuruan because he helped and involved in modernizing the management of mosque who has proposed to save any fund of mosques in bank. However, this institution is not always led by the anti-Islamic chairman such as Rinkes, but also led by moderate chairman such as Snouck and Hazeu, or headed by Van der Plas, Kern and Gobee who strongly supported native people in actualizing the freedom of religion and culture, even often their policy created conflicts with the colonial government (Suminto, 1985 p. 162-169, 205-211).

These intimidate policies raised the sporadic oppositions from Islamic organizations such as SI, NU, Muhammadiyah, and the association of penghulu ${ }^{2}$ which held protests in different places in Java against the colonial government. Although they have initiated some efforts to organize themselves in some congresses of MAIFHS (the Congress of Muslim in the Netherland East Indies) in Bogor (1926) and Pekalongan (1937) as an attempt to counter the Dutch interference on Muslim activities that was contrary to the principle of religious-neutral policies (Suminto, 1985, p. 32).

The shift of colonial power from the Dutch to Japan did not eliminate the aspects of politicization of Islam (Ricklefs, 2013, p. 121). Japan wished to foster political spirit by prioritizing the role of the traditional ulama in order to mobilize the Islamic political organizations to support the political interests of Japan in the Asia Pacific region. Japanese efforts to establish the Office of Religious Affairs (Shumubu) in 1944 and entrusted its management to native people from a traditional Javanese ulama (NU), Wahid Hasyim, is a portrait of a strong desire of the Japanese colonialism to politicize Islam (Dhofier, 2011, p. 178). This is in contrast with the policy of the Netherlands that has never entrust an important position in the Office of Indigenous Affairs to the natives and even has strictly restrict and prohibit the movement of traditional ulama. It was caused by the willingness of the Dutch colonialism to take control of the coloni areas and to suppress selective policies to potentially radical Islamic and nationalist movements.

Benda (Benda, 1958, p. 108-110) argues that the power of Islam is more important for Japan in order to instilling the stigma of anti-Dutch colonialism, on the other hand, it potentially evoked solidarity of the people of Eastern nation as a political affinity to manipulate the natives. The

${ }^{2} \mathrm{~A}$ person in charge to authorize the legality of a marriage in Islam. 
formation of MIAI (the forum of Indonesian Muslim) was a milestone of the agglomeration of Indonesian Islamic political forces, particularly Islamic organizations based in Java, which has never happened before. This unification was the forerunner to the formation of a political party, Masjumi, which indirectly increased the bargaining power of political Islam against the secular-nationalist groups in post-independence Indonesia (Latif 2008, p. 214-215).

\section{CONCLUSION}

Islamization in Java in the early 20th century is a dynamic and gradual process that affected by, first, the ethical policies of the colonial government; second, the transmission of Islam from the Middle East; and, finally, the politicization of Islam under the colonial government. The creation of a public space for political contestations has developed a new identity of Indonesian elite that was no longer manipulated by priyayi that has genetically determined, but this identity was emphasized by the level of education, economy and leadership in progressive organizations. The dynamic process of Islamization in rural and urban areas has formed a new collaboration of priyayi-santri and santriabangan that affected abangan to merge with the identity of santri, and syncretism, although still there, increasingly eroded by mainstream Islam. The transmission of Islam from the Middle East has caused the ongoing process of Islamic revitalization (Islamization) in Java conducted by modernist Islam and traditional Islam. The modernist Islam strengthened its position by creating structured and modern organizations that concentrated in urban areas, whereas the traditional Islam has developed an intellectual genealogy through pesantren networks scattered in the rural areas. The politicization of Islam that has been done by the colonial government strengthened the existence of Islamization process through communal and sporadic responses, or even has an impact on the unification of Islamic institution. 


\section{References}

Abaza, Mona. (1999). Pendidikan Islam Dan Pergeseran Orientasi: Studi Kasus Alumni Al-Azhar. Jakarta: LP3ES.

Abdullah, Taufik. (1987). Islam Dan Masyarakat: Pantulan Sejarah Indonesia. Jakarta: LP3ES.

Abushouk, Ahmed Ibrahim. (2001). A Sudanese Scholar in the Diaspora: Life and Career of Ahmad Muhammad Al-Surkitti in Indonesia (191I-1943). Studia Islamika 8 (1), pp. 55-86.

Abushouk, Ahmed Ibrahim. (2007). Al-Manar and Hadrami Elite in the Malay-Indonesian World: Challenge and Response. Journal of Royal Asiatic Society Series 317 (3): 301-322.

Ahnaf, Mohammad Iqbal. (2016). Tiga Jalan Islam Politik Di Indonesia: Reformasi, Refolusi Dan Revolusi. Wawasan: Jurnal IImiah Agama Dan Sosial Budaya 1 (2), pp. 1. doi:10.15575/jw.v1i2.728.

Al-Attas, Syed Naquib. (1991). The Concept of Education in Islam: A Framework for an Islamic Philosophy of Education. Kuala Lumpur: ISTAC.

Al-Faruqi, Ismail Raji. (1988). Islam, Source and Purpose of Knowledge. Herdon, Virginia: IIIT.

Azyumardi Azra. (1999). The Transmission of Al-Manar's Reformism to the Malay-Lndonesian World: The Cases of Al-Lmam and Al-Munir. Studia Islamika 6 (3), pp. 75-100.

Benda, H.J. (1958). The Crescent and the Rising Sun. The Hague: W. van Hoeve Ltd.

Bruinessen, Martin Van. (1995). Kitab Kuning, Pesantren Dan Tarekat: Tradisi-Tradisi Islam Di Indonesia. Bandung: Mizan.

Crawfurd, John. (1820). History of the Indian Archipelago, Containing an Account of the Manners, Arts, Languages, Religions, Institutions, and Commerce of Its Inhabitants. In , II. Edinburgh: Archibald Constable.

Dhofier, Zamakhsyari. (2011). Tradisi Pesantren: Studi Pandangan Hidup Kyai Dan Visinya Mengenai Masa Depan Indonesia. Jakarta: LP3ES.

Djajadiningrat, Hoesein. (1913). Critische Beschouwing van de Sadjarah Banten. Haarlem.

Ember, Carol R, and Melvin Ember. (1994). Konsep Kebudayaan. In Pokok-Pokok Antropologi Budaya, edited by T. O. Ihromi. Jakarta: Yayasan Obor Indonesia.

Feillard, Andree. (2011). The Constrain Place of Local Tradition: The Discourse of Indonesian Traditionalist Ulama in 1930s. In The Politics of Religion in Indonesia: Syncretism, Orthodoxy, and Religious Contention, edited by Michel Pikard and Remy Madinier.

Geertz, Clifford. (1961). Review of the Book The Emergence of the Modern Indonesian Elite, by Robert van Niel. American Anthropologist 63 (3).

Geertz, Clifford. (1973). The Interpretation of Culture. New York: Basic Books Inc.

Geertz, Clifford. (1976). The Religion of Java. Chicago \& London: The University of Chicago Press. 
Geertz, Clifford. (2001). Near East in the Far East on Islam in Indonesia. Paper Number 12.

Geusau, W.H. Alting von. (1917). Neutraliteit Der Overheid in de Nederlandsche Kolonien Jegens Godsdientzaken. Haarlem. In Politik Islam Hindia Belanda, edited by Aqib Suminto. Jakarta: LP3ES.

Hebermas, Jurgen. (1991). The Structural Transformation of the Public Sphere: An Inquiry into a Category of Buorgeois Society. Massachusetts: MIT Press.

Ismail Raji Al-Faruqi. (1982). Islamization of Knowledge: General Principles and Workplan. Herdon, Virginia: IIIT.

Johns, Anthony H. (1993). Islamization in Southeast Asia: Reflections and Reconsiderations with Special Reference to the Role of Sufism. Southeast Asian Studies 31 (1).

Kahfi, Erni Haryanti. (2001). Islam and Nationalism: Agus Salim and Nationalist Movement in Indonesia during the Early Twentieth Century. Jakarta: Logos Wacana IImu.

Korver, A.P.E. (1985). Sarekat Islam: Gerakan Ratu Adil? Jakarta: Grafiti Press.

Latif, Yudi. (2008). Indonesian Muslim Intellegensia and Power. Singapore: ISEAS.

Lukas, Helmut. (2002). The Perception of Indonesia's History and Culture by Western Historians and Social Scientists. Brussels: Unpublished Seminar Paper.

Madjid, Nurcholish. (2013). Islam, Kemoderenan Dan Keindonesiaan. Bandung: Mizan.

Nasution, S. (2001). Sejarah Pendidikan Indonesia. Jakarta: Bumi Aksara.

Nazwar, Akhria. (1983). Ahmad Khatib: IImuwan Islam Di Permulaan Abad Ini. Jakarta: Pustaka Panjimas.

Niel, Robert van. (1960). The Emergence of Modern Indonesian Elite. Chicago: Quadrangle Book.

Noer, Deliar. (1973). The Modernist Muslim Movement in Indonesia 1900-1942. Kuala Lumpur: Oxford University Press.

Noer, Deliar. (2000). Partai Islam Di Pentas Nasional: Kisah Dan Analisis Perkembangan Politik Indonesia 1945-1965. Bandung: Mizan.

Pranowo, Bambang. (2011). Memahami Islam Jawa. Jakarta: Pustaka Alvabet.

Raffles, Thomas Stamford. (1830). The History of Java,Vol. 2. London: John Murray. Cited from Ricklefs, M.C. (2007), Polarising Javanese Society: Islamic and Other Visions C. 1830 1930. Leiden: KITLV Press.

Raharjo, Supratikno. (2002). Peradaban Jawa: Dinamika Pranata Politik, Agama, Dan Ekonomi Jawa Kuno. Jakarta: Komunitas Bambu.

Ricklefs, M.C. (2007). Polarising Javanese Society: Islamic and Other Visions C. 1830-1930. Leiden: KITLV Press.

Ricklefs, M.C. (2008). "Religious Reform and Polarization in Java." ISIM Review 12. 
Ricklefs, M.C. (2013). Mengislamkan Jawa: Sejarah Islamisasi Di Jawa Dan Penentangnya Dari 1930 Sampai Sekarang. Jakarta: Serambi.

Shiraishi, Takashi. (1990). An Age in Motion, Popular Radicalism in Java 1912-1926. Ithaca and London: Cornell University Press.

Suminto, Aqib. (1985). Politik Islam Hindia Belanda. Jakarta: LP3ES.

Susen, Simon. (2011). Critical Notes on Habermas's Theory of the Public Sphere, Sociological Analysis. 5 (1).

Taylor, Jean Gelman. (2003). Indonesia: Peoples and Histories. New Haven and London: Yale University Press.

Yusuf, Slamet Effendy, Mohamad Ichwan Syam, and Masdar Farid Mas'udi. (1983). Dinamika Kaum Santri: Menelusuri Jejak Dan Pergolakan Internal NU. Jakarta: CV. Rajawali. 
The Pattern of Islamic Moderate Movement in Java under Political Fluctuations in Early 20th Century 